\title{
CIÊNCIA E RELIGIÃO: por uma micropolítica de subjetivação
}

\author{
Pasqualino Romano Magnavita
}

\begin{abstract}
O texto resulta da inserção do autor em um novo Plano de Imanência filosófico, utilizando novos conceitos em uma nova forma de pensar de natureza diferente da forma de pensar binária e ainda hegemônica. Qualquer religião constitui um Saber (teológico), e, portanto, trata-se de uma estratificação histórica de conhecimentos, normas e práticas (que se dobram no interior dos indivíduos, promovendo a construção de um Território Existencial individual ou coletivo), todavia, de natureza transcendente, ou seja, a crença em um mundo além do nosso. $\mathrm{O}$ pensamento contemporâneo considera a indissociabilidade da relação Saber/Poder e também dos processos de subjetivação. O texto é fundamentado na tríade conceitual da Imanência: Saber, Poder e Subjetivação. Todavia, constata-se uma certa afinidade da Ciência com a Teologia ("Ciência" de poderes transcedentes, espirituais), a qual coexiste e pouco contesta a "tirania" do aparelho de Estado dos poderes materiais das atuais "Sociedades de Controle". Diversamente, o ateísmo se caracteriza por sua crença (fé) na Imanência e evidencia a Ética ("visão de mundo") como atitude política visando a emancipação do controle social existente.

PAlavras-ChavE: Estratos. Território Existencial. Saber/Poder. Dobra. Subjetivação.
\end{abstract}

A religião é o ópio do povo Karl Marx O Ateísmo não é um drama, mas a serenidade do filósofo e a conquista da filosofia. Gilles Deleuze Deus não morreu, Ele tornou-se dinheiro. Giorgio Agamben

\section{INTRODUÇÃO}

O pensamento do autor se situa no âmbito da "Revolução Cultural" ocorrida no final da década 1960 do século XX, adotando a nova forma de pensar conhecida como pensamento rizomático (filosofia da diferença). Tal pensamento pressupõe um plano de imanência (filosófico) e um novo repertório conceitual em que o pensamento se orienta para pensar, pois a filosofia, como forma de pensar e criar, visa basicamente a traçar um plano e a criar conceitos. Trata-se da nova lógica (da multiplicidade), de outra forma de pensar e, portanto, diferente do pensamento dialético e de sua lógica binária, herdado da modernidade e, todavia, ainda hegemônico.

Opensamentorizomático equivale a umapragmática, ou seja, visa a criar e a resolver problemas. Também é uma estratoanálise, pressupondo os con-

* Doutor em Arquitetura. Professor aposentado da Universidade Federal da Bahia. Integra o quadro docente do Programa de Pós-graduação em Arquitetura e Urbanismo da UFBA. Pesquisador do CNPq).

Rua Caetano Moura, 121. Cep: 40210-350. Federação - Salvador - Bahia - Brasil. pasqualinomagnavita@terra.com.br ceitos de estratos (estratificação), agenciamentos (ações), território e desterritorialização (linha de fuga). Trata-se de uma micropolítica (processos de subjetivação), e ainda, de uma esquizoanálise, ou seja, uma totalidade segmentária. Esse pensamento vem "desconstruindo" os conceitos clássicos de uno (unidade), totalidade, identidade, continuidade, evolução (linear), organismo, estrutura e sistema, entre muitos outros conceitos ainda dominantes no plano de imanência do pensamento dialético. Por sua vez, o pensamento rizomático vem evidenciando os conceitos de multiplicidade, heterogeneidade, totalidade segmentária, diferença, descontinuidade, evolução a-paralela (não linear), corpo sem órgãos, Rede aberta, entre outros conceitos, e isso visa a torná-los hegemônicos, em lugar dos clássicos conceitos herdados.

\section{PRESSUPOSTOS CONCEITUAIS (CATEGORI- AS DE ANÁLISE)}

Tratando-se de uma forma de pensar contemporânea, a intenção de apresentar alguns pres- 
supostos conceituais tem o objetivo de esclarecer ao leitor algumas questões e referências conceituais que fundamentam este texto, facilitando, assim, o entendimento do tema proposto pelo Grupo de Ética da Academia de Ciências da Bahia: ciência e religião. Trata-se de tema complexo e de caráter existencial, que poderá levar o leitor a um possível entendimento do que seja uma micropolítica de subjetivação, como se verá a seguir.

O primeiro pressuposto diz respeito à existência de três universos coexistentes e simultaneamente relacionados, os quais constituem a complexidade da própria existência. São eles: o universo cósmico (sideral), caracterizado pela incomensurável apreensão de seus infinitos espaços e configurado por imprevisíveis dinâmicas de corpos e sistemas abertos (planetas, galáxias, nebulosas, buracos negros entre outros), sob a égide do tempo deAion, incomensurável, ou seja, da eternidade sem princípio nem fim e dos instantes de criações (acontecimentos) de diferentes elementos que nele emergem e se transformam, acompanhando a variação contínua do universo e de sua existência; o universo macro (molar), do mundo da apresentação (denominado, também, mundo da representação), o lugar do real e do possível, da fenomenologia, do tempo mensurável, cronos (passado, presente e futuro) e da macropolítica, caracterizado pelas manifestações de exterioridade dos saberes e da invisibilidade do exercício de poderes, sob a égide da lógica do sentido, ${ }^{1}$ lugar por excelência do pensamento dialético com sua lógica binária - trata-se do pensamento ainda dominante do sensível, da lógica da sensação; o universo micro (molecular) do par conceitual virtual e atual, universo de intensidades, fluxos, desejos, quanta, caracterizado pela invisibilidade de seus agenciamentos e da matéria não formada (sem forma) e onde ocorrem os processos de subjetivação individual e (ou) coletiva e, portanto, o exercício da micropolítica, sendo, também, o lugar da criatividade. Énesse último universo que emerge o pensamento rizomático como micropolítica, com sua lógica da multiplicidade,

${ }^{1}$ Sobre a dupla dimensão do Tempo (Cronos e Aion), ver Lógica do Sentido (Deleuze, 1998, p.167). pensamento ainda pouco assimilado, mesmo no ambiente acadêmico, onde predomina ainda o pensamento da lógica binária, a dialética.

O segundo pressuposto relaciona-se com as três formas de pensar e criar: filosofia, ciência e arte. A filosofia cria conceitos com seu plano de imanência; a ciência cria funções (functivos) com seu plano de referência; e a arte cria percepções (perceptos) e afetos, com seu plano de composição. Essas três formas se cruzam, se entrelaçam sem síntese nem identificação ou prioridade de uma dessas formas sobre as outras e fazem do pensamento uma heterogênese. O clímax desse pensamento se caracteriza quando o conceito (filosofia) se torna conceito de função (ciência) e conceito de sensação (arte). Ou então, quando a função (ciência) se torna função de conceito (filosofia) e função de sensação (arte). Ou ainda, quando a sensação (arte) se torna sensação de conceito (filosofia) e sensação de função (ciência).

O terceiro pressuposto relaciona-se com a tríade conceitual: saber, poder e subjetivação. Os saberes (conhecimentos) são indissociáveis das relações de poder e pressupõem processos de subjetivação individuais e coletivos São três conceitos que pressupõem questões de diferente natureza, pois não se identificam, mas coexistem e se pressupõem reciprocamente.

O quarto pressuposto se relaciona com a $\mathrm{ex}^{-}$ periência individual e (ou) coletiva, como "território existencial" autorreferente. A experiência, em sua efetuação, pressupõe uma "visão de mundo", ou seja, um envolvimento político, como atitude ética. A propósito, vale lembrar que, na modernidade, o paradigma no campo da estética era o da autonomia da arte, ou seja, a "arte pela arte". Portanto, tratava-se de um paradigma basicamente estético. Não se discutia a quem a produção da arte era destinada. Hoje, a grande produção das diferentes manifestações artísticas ocorre não mais sobre a égide do capitalismo industrial das "sociedades disciplinares" (Foucault), mas do atual capitalismo pós-industrial das "sociedades de controle" (Deleuze). Justamente, frente a essa nova realidade e na qual se constata a crescente desigualdade so- 
cial, emerge, à guisa de resistência a essa produção, o novo paradigma ético-estético. Não mais a arte pela arte, embora mantida sua dimensão estética, a produção no universo da arte deve ser acompanhada de sua dimensão ética, ou seja, uma atitude de micropolítica de subjetivação dos produtores de arte em geral, à guisa de uma atitude política, um contra-poder de "resistência criativa" (ou emancipação criativa) à produção artística a serviço das corporações que dominam e configuram a atual produção hegemônica. Ao lado do paradigma ético-estético, emergem tanto o paradigma ético-científico, bem como, o paradigma ético-filosófico.

O sexto pressuposto diz respeito ao par conceitual diferença e repetição, pois nada permanece igual a si mesmo. Não existem "coisas em si", pois as coisas são relações e resultam de imprevisíveis e contínuas conexões que caracterizam a variação permanente da existência, sem princípio nem fim. As "coisas" se repetem na diferen$c ̧ a$, a qual pode ser apenas uma diferença de grau e (ou) de nível (repetições, interpretações), ou então uma diferença de natureza, e isso, quando ocorre um acontecimento, uma criação, uma inovação paradigmática, um devir-outro da existência. A lógica da diferença, também conhecida como lógica da multiplicidade, sustenta o plano de imanência filosófico, constituindo o pensamento rizomático e seu repertório conceitual. A filosofia da diferença vem "desconstruindo", ou seja, substituindo a ontologia clássica e moderna da identidade das "coisas em si", das "essências".

O sexto pressuposto relaciona-se com o conceito criatividade. Nesse sentido, parte-se do seguinte entendimento: existem dois elementos comuns a todos os seres humanas - diferença e criatividade-, pois, somos todos diferentes e, ao mesmo tempo, diferentemente criativos. Contudo, a criatividade se manifesta em diferentes níveis e graus, seja sobre coisas já criadas (interpretações), seja a criatividade com diferença de natureza (algo, de fato, novo, paradigmático). Vale lembrar que a criatividade, hoje, na atual fase do capitalismo pós-industrial, como bem imaterial, passou a ser a matéria-prima de seus investimentos (patentes direitos autorais de grandes empresas e diferentes corporações).

O sétimo pressuposto decorre do frequente uso, inclusive na academia, dos seguintes conceitos: povo, massa, comunidade, comum, os quais têm presença garantida na forma de pensar dialética do mundo da representação, como macropolítica. Tais conceitos pressupõem o convívio com os conceitos de unidade, identidade, homogeneidade, pois somos todos iguais perante a lei e no seio da Nação. Todavia, no pensamento contemporâneo, emerge um diferente conceito: multidão. Na modernidade, esse conceito era discursivamente atualizado de forma pejorativa, como manifestação social considerada temível e que competia ao Governo controlar. Hoje, o entendimento discursivo desse conceito é diferente, pois o conceito multidão passa a ter um novo sentido, a exemplo de uma totalidade segmentaria (informal) constituída por uma multiplicidade e heterogeneidade de indivíduos e se caracteriza pela descentralidade das ações de seus integrantes, que são centrífugas, pelas trajetórias nômades que eles percorrem e pela presença anônimas de suas realizações. Tanto a ciência quanto a religião devem pressupor, em suas práticas, o conceito discursivamente atualizado de multidão, seja na difusão de conhecimentos científicos ou teológicos que afetam multidões.

O oitavo pressuposto relaciona-se com a adoção do princípio da indeterminação, conhecido também como princípio da incerteza (Heisenberg), pois, o pensamento rizomático como processo aberto, sem princípio e sem fim, encontra-se sempre no meio, no entre, no intermezzo de multiplicidade e heterogeneidade de imprevisíveis conexões, no sentido de contínuas conjunções e (indeterminação), em lugar do verbo ser, do é (determinação), pois, pressupõe descontinuidades (rupturas a-significantes), evoluções não lineares (evoluções a-paralelas) e performances (criações), em lugar de decalques (reproduções).

O nono pressuposto relaciona-se com o enfrentamento do pensamento com o caos, e isso não como sinônimo do conceito desordem, em oposição à ordem, mas caos como lugar de todas as for- 
mas, lugar da criação, o "oceano da dessemelhança” (Deleuze; Guattari). Pois o que caracteriza o caos é menos a ausência de determinações que a velocidade infinita com a qual elas se esboçam e se apagam, pois não é um movimento de uma a outra, mas a impossibilidade de uma relação entre duas determinações, já que uma não aparece sem que a outra tenha já desaparecido. O caos desfaz, no infinito, toda consistência. A filosofia, com seu plano de imanência, enfrenta o caos na velocidade infinita do pensamento, para dar consistência à criação de conceitos. A ciência não enfrenta o caos, pois ela desacelera a velocidade infinita, criando um plano de referência com suas funções. A arte parte do finito do real e do possível para atingir a infinitude do caos, lugar da criação. Portanto, navegar no caos é preciso!

\section{CIÊNCIA, RELIGIÃO E A RELAÇÃO ENTRE SABER E PODER (ESTRATIFICAÇÕES HISTÓ- RICAS)}

Este texto, que relaciona ciência e religião, será conduzido no âmbito dos pressupostos acima estabelecidos, pois tanto a ciência como a religião são consideradas estratos, como específicos saberes (conhecimentos) indissociáveis de específicas relações de poder. Os termos saber e conhecimentos, embora epistemologicamente distintos, neste texto, terão o mesmo entendimento, ou seja, será utilizado mais o termo saber no sentido amplo, de conhecimento de qualquer natureza, como estratificações históricas, incluindo os saberes religiosos que emanam, todavia, de pressupostos transcendentes, que vão além do real e do possível do mundo da representação no qual vivemos, ou seja, do além-mundo. Nesse sentido, torna-se necessário atualizar discursivamente o conceito de estratos (estratificações), pois os saberes são estratificações históricas (Foucault, 1981). Torna-se necessário, portanto, atualizar discursivamente esse conceito:

Os Estratos são fenômenos de espessamento do corpo da terra, ao mesmo tempo moleculares e molares: acumulações, coagulações, sedimenta- ções, dobramentos. São Cintas, Pinças ou Articulações. Tradicionalmente, distinguem-se, de modo sumário, três grandes estratos: físico-químico, orgânico, antropomórfico (ou “aloplásticos"). Cada estrato, ou articulação, é composto de meios codificados e substâncias formadas. Formas e substâncias, códigos e meios não são realmente distintos. São componentes abstratos de qualquer articulação" [...] Os estratos possuem grande mobilidade, pois um estrato é sempre capaz de servir de substrato a outro, ou de percutir um outro e ocorrem fenômenos de interestados, transcodificações e passagens de substâncias (meios), misturas. [...] A estratificação é a criação do mundo a partir do caos, uma criação contínua, renovada, e os estratos constituem [...] o Juízo de Deus. O artista clássico é como Deus, ao organizar as formas e as substâncias, os códigos e os meios, e os ritmos, ele cria o mundo (Deleuze; Guattari, 2008 p.16-17, grifo nosso).

A articulação, como constitutiva de um estrato, é sempre uma dupla articulação, à guisa de uma dupla pinça: articula uma expressão e um conteúdo, tendo cada um por sua conta, forma e substância, ou seja, código e meio. Vale salientar que, entre expressão e conteúdo, não existe correspondência, nem relação de causa e efeito, nem relação de significado e significante; há distinção real e pressuposição recíproca. Entretanto, não é da mesma maneira que expressão e conteúdo se distinguem em cada estrato, pois os três estratos acima mencionados não possuem a mesma repartição e o molar e molecular, segundo o estrato considerado, entram em combinações muito diferentes.

Entretanto, a questão é caracterizar o movimento que nos conduz para fora dos estratos, pois os estratos físico-químicos não esgotam a matéria, e existe uma matéria não formada, submolecular. Igualmente, os estratos orgânicos não esgotam a vida, pois o organismo é aquilo a que a vida se opõe para limitar-se, pois existe uma vida mais poderosa, não orgânica (anorgânica, um corpo sem órgão desejante), e ainda existem os devires não humanos do homem nos estratos antropomórfico (culturais). A desestratificação implica extravasar o organismo, lançar-se num devir, e exige uma prudência extrema, pois qualquer desestratificação violenta corre o risco de ser suicida, cancerosa, levando ao vazio, à destruição, pois os estratos endurecem, perdem os seus graus de diversidade, de dife- 
renciação e de mobilidade. Por exemplo, os "estados de exceção”, os fascismos, são desestratificações violentas dos estratos como saberes políticos, sociais e culturais.

\section{AGENCIAMENTOS, TERRITÓRIOS, DESTERRITORIALIZAÇÃO (LINHA DE FUGA)}

Os agenciamentos são algo diferente dos estratos. Entretanto, eles se efetuam nos estratos e operam em zona de descodificação dos meios e extraem dos meios um território, pois todo agenciamento é, antes de tudo, territorial, e o território é feito de fragmentos descodificados de todo o tipo, extraídos dos meios, mas adquire um valor de "propriedade". Nesse sentido, pode-se afirmar que o território cria o agenciamento. Mesmo territoriais, os agenciamentos continuam pertencendo aos estratos, embora, em qualquer estrato, se possa distinguir a expressão e o conteúdo. Vale considerar que o agenciamento não se reduz aos estratos, porque, nele, a expressão torna-se um sistema semiótico, um regime de signos, e o conteúdo, um sistema pragmático, ações e paixões, ou seja, agenciamentos coletivos de enunciação e agenciamentos maquínicos. É a dupla articulação rosto e mão, fala e gesto, o que se diz e o que se faz. Nesse sentido, tanto a ciência quanto a religião pressupõem esses agenciamentos, pois são saberes produzidos socialmente e, portanto, diz-se e faz-se, e isso como individuação sem sujeito, pois se trata de uma construção social e não propriamente individualizada.

O agenciamento, por sua vez, apresenta-se por outro eixo. Sua territorialidade em relação à expressão e ao conteúdo é apenas uma primeira caracterização. A segunda diz respeito às linhas de desterritorialização que o atravessam e o arrastam. Justamente por isso, o território é inseparável da desterritorialização, e suas linhas são denominadas linhas de fuga, Segundo essas linhas, o agenciamento já não apresenta expressão nem conteúdo distintos, porém matérias não formadas, forças e funções desestratificadas. Resumindo, há uma tetravalência do agenciamento: em primeiro lugar, expressão e conteúdo; em segundo lugar, territorialidade e desterritorialização.

\section{PLANO FILOSÓFICO}

Tanto a ciência quanto a religião utilizam um diferente plano filosófico em que o pensamento se orienta para pensar A ciência, predominantemente, utiliza o plano de imanência, que se relaciona com o real e o possível do universo molar, e também do universo micro (molecular do virtual e atual, atualização discursiva). A religião, por sua vez, utiliza o plano de transcendência, ou seja, considera a existência de entidades, forças e poderes, pressupondo sempre uma imaginada origem e destinação da existência. Vale salientar que, para a grande maioria dos seres humanos, inclusive renomados cientistas, esses dois planos filosóficos coexistem neles, como veremos a seguir, particularmente, quando se vem tentando aproximar a ciência da religião, ou seja, o conhecimento imanente da ciência do conhecimento transcendente da religião (teologia).

Considerando o que se afirmou anteriormente, o saber, em qualquer área de conhecimento, constitui uma estratificação história e, portanto, como estrato, pressupõe a dupla articulação agenciada e constitui o território de um determinado saber, seja ele científico, seja religioso. Portanto, tanto o saber religioso quanto o saber cientifico, em primeira instância, se caracterizam pelos agenciamentos coletivos de enunciação (o que basicamente se diz, se enuncia) e agenciamentos maquínicos (o que se faz, ações, paixões, práticas científicas ou religiosas, entre outras). Os saberes como estratos, indissociáveis dos agenciamentos, como poderes, constituem territórios que se caracterizam pela exterioridade das manifestações dos saberes (o que se diz e o que se vê, as palavras e a coisas) e pela invisibilidade dos poderes no exercício de suas ações. Via de regra, nas instituições de ensino e pesquisa, apenas o saber é relevado, pois se pressupõe a neutralidade do saber, o que, 
de fato, não ocorre, pois qualquer transmissão de conhecimento pressupõe uma relação de poder.

Os saberes, estratos caracterizados pelo seu movimento em variação contínua, são transmitidos em ações coletivas de enunciação como verdades (sejam eles dogmas, revelações, prescrições, ou então verdades, enunciados, proposições, lógicas científicas). Normalmente, essa transmissão de saberes e poderes se configura como uma palavra de ordem, como uma crença, ou seja, um ato de fé naquilo em que se acredita. Entretanto, essa transmissão, via de regra, é impessoal (o que se diz, diz-se) e revela uma relação a qual se configura no par conceitual saber e poder, o que, ao mesmo tempo, pressupõe uma experiência individual ou coletiva daquilo que se diz e do que se vê. $\mathrm{E}$ isso ocorre através de um dobramento, ou seja, da "dobra" (uma inflexão) desse saber e poder no "dentro" do indivíduo, ou em um grupo de indivíduos, promovendo uma relação de si para si mesmo, para com os outros, e para com o mundo.

Esse dobramento caracteriza um contínuo processo de introspecção, de apreensão daquilo que se expressa pela exterioridade de suas manifestações, o que se diz e o que se faz, indissociável da invisibilidade das ações (poderes) que acompanham essas manifestações. Essa interiorização denominou-se processo de subjetivação, o qual pode ser individual ou coletivo, no sentido de uma construção, uma fabricação da subjetividade. Dessa forma, completa-se a tríade conceitual foucaulteana saber-poder-subjetivação, ou seja, os diferentes saberes-poderes dominantes ou os contra-saberespoderes de resistência existentes são interiorizados (dobrados) em cada indivíduo ou em um grupo social, caracterizando, assim, os processos de subjetivação. Tanto a ciência quanto a religião incorporam esses processos de subjetivação e, no pensamento adotado por esse autor, eles constituem o universo da micropolítica de subjetivação.

Essa construção da subjetividade individual ou coletiva pressupõe que esses saberes-poderes dobrados adotem uma forma de pensar, ou seja, um plano filosófico (de imanência ou transcendência, ou mesmo na interface entre esses dois planos, ambos acompanhados de seus respectivos repertórios conceituais). Dependendo da forma de pensar, dos conceitos e da lógica utilizada, as crenças, sejam elas de que natureza for, se evidenciam. Vale lembrar, como já se afirmou anteriormente, que o pensamento ainda dominante no mundo é a forma de pensar dialética, ou seja, o uso dos conceitos criados no pensamento clássico e moderno sob a égide da lógica binária, como oposição dos predicados. Oposição que constitui uma das quatro ilusões do mundo da representação (do universo macro do real e do possível). Tal ilusão se soma às outras três: "identidade do conceito" $(\mathrm{A}=\mathrm{A})$; "analogia do juízo" e "semelhança do percebido" (efeitos se superfície) (Deleuze, 1988).

No pensamento dominante, a atualização discursiva de conceitos se dá em estados de coisas, corpos ou vividos. Os conceitos dominantes ainda são: unidade, identidade, totalidade (o todo e suas partes, que se encaixam à guisa de um quebra-cabeça), continuidade, homogeneidade, evolução (linear, com base no conceito progresso), organismo, estrutura, sistema, e os pares conceituais princípio (origem) e fim, causa e efeito, ordem e desordem (caos), entre outros conceitos e pares conceituais herdados da modernidade.

Tomemos, por exemplo, o conceito organismo, que é um virtual (incorporal) que se atualiza discursivamente em estados de coisa, corpos e vividos, no caso, no organismo humano, demarcado pelo ciclo da vida, do nascimento à morte, nascer e, inapelavelmente, morrer. Tal fato caracteriza o par conceitual princípio e fim, ou seja, os dois limites da vida: nascer e morrer. Por analogia do juízo (uma das ilusões do mundo da representação), em função dessa presença visível do princípio da vida de qualquer ser humano, animal ou vegetal (nascimento e morte de qualquer espécie), estende-se esse par conceitual a todas as coisas e circunstâncias, quando o pensamento se orienta para pensar. Nesse, sentido, admite-se que a existência, o universo em sua incomensurabilidade, também deve ter um princípio, uma origem, um início em sua formação e terá um fim (o esperado "fim do mundo", tão presente na história do ima- 
ginário humano, o Apocalipse). Dessa concepção dual, nasce a necessidade da racionalidade dialética de um princípio primeiro, ou seja, a existência de um criador do universo, do céu e da terra e de todas as coisas, inclusive do homem.

Essa necessidade de um Deus ou de deuses resultou da presença de fenômenos naturais, frente à indeterminação e à variação contínua da existência de temível ocorrência (terremotos, dilúvios, ciclones, maremotos, raios e trovoadas), à presença alternada do sol e da lua no céu de constelações, entre outras evidências, e da impossibilidade de encontrar uma explicação em tudo que se percebia. Então, passou-se a imaginar que deveriam existir entidades sobrenaturais responsáveis por essas manifestações. A ideia de uma única entidade nasceu da necessidade racional de estabelecer uma origem, uma criação do universo, do céu e da terra e de todas as coisas, plantas e animais, inclusive, do homem. Ideia consolidada historicamente pelas três grandes religiões monoteístas (hebraica, cristã e islâmica): um Ser único, Deus onipotente (tem poder ilimitado), onisciente (tem um saber incomensurável) e onipresente (encontra-se sempre presente em qualquer lugar), sem princípio e nem fim, mas, eterno! Estranho que, em sua infinita dimensão, Deus tenha sido imaginado à semelhança do homem. Vale lembrar que a diferença entre um crente e um ateu consiste em que o primeiro crê que Deus criou o homem; o segundo afirma que Deus é criação do homem à sua semelhança, pois possui os sentidos e sentimentos humanos: sabe, vê, ama, tem vontade, é bom, misericordioso, justo, comanda, decide, perdoa, mas também castiga.

No âmbito da filosofia, o conceito Deus é um virtual, um incorporal criado como todo conceito e, portanto, autorreferente. Como saber (teológico) se atualiza (atual), discursivamente, como agenciamento coletivo de enunciação em estados de coisas, corpos e vividos e se caracteriza pela semelhança com os seres humanos. Os livros sagrados são esses agenciamentos que expressam e, ao mesmo tempo, poderes transcendentes, divinos. Entretanto, como conhecimento teológico,
Deus é um produto de prolongada estratificação histórica (estrato), que tem se evidenciado ao longo do tempo em multiplicidade e heterogeneidade de deuses, entidades e espíritos, e isso em decorrência de um específico meio físico, no entre circunstância de sobrevivência, no intermezzo de situações e contextos sociais e políticos, assumindo, diferentes configurações e sentidos. Todavia são entidades sempre imaginadas à semelhança do homem, não apenas no monoteísmo, mas também no politeísmo.

Basicamente, a multiplicidade e a heterogeneidade de religiões, via de regra, pressupõem uma tríade que as caracterizam: Deus (ou deuses), a imortalidade da alma (o desejo de continuar vivendo depois da morte) e o livre arbítrio (um questionável pressuposto). Embora os dois primeiros sejam questões intangíveis, o livre arbítrio, que resulta de uma delegação de Deus (imaginado pelo próprio homem), pressupõe um direito de pensar e agir, e isso, como direito, ao mesmo tempo, estabelece ou cria um imperativo categórico, ou seja, uma responsabilidade inadiável e, todavia, sempre presente, acompanhada de um sentimento de culpa, frente à não superação das adversidades existentes em uma formação social.

O que seria, hoje, o livre arbítrio frente à complexidade do emaranhado das relações sociais e determinações de saberes-poderes hegemônicos das atuais sociedades de controle, extremamente competitivas e voltadas para o modo de produção material e imaterial, embora direcionadas para o consumo e a espetacularização da vida? Frente aos processos midiáticos das tecnologias avançadas no âmbito de uma exaustiva globalização do Planeta caracterizada pela enorme desigualdade social existente, violência, guerras, terrorismo, drogas, catástrofes naturais, entre outras ocorrências -, um crente apenas diria passivamente: "seja feita a vontade de Deus"? Considerando que os seres humanos são construções históricas, sociais, políticas e culturais em suas formações subjetivas, o livre arbítrio somente teria sentido, como veremos mais adiante, como atitude ética, ou seja, "visão de mundo" e como resistência criativa ao controle social existen- 
te, ou seja, à vontade de poder, de criação da vida!

De um lado, a crença religiosa voltada para a origem do universo como ato de fé; do outro lado, a ciência, em sua compreensão dialética, também acredita que o universo deve ter tido uma origem, um princípio, colocando em questão os saberes atuais da ciência submolecular das partículas, ou os saberes existentes sobre o universo sideral (astrofísica). Vale lembrar a polêmica teoria do big-bang, da suposta explosão cósmica ocorrida entre 10 a 20 bilhões de anos. Entretanto, mesmo caracterizada a origem através de supostos elementos e (ou) partículas (vale lembrar a recente "partícula de Deus", assim enunciada por um cientista), ou de um hibrido e estranho entendimento entre religião e ciência, promovido pela cientologia, ${ }^{2}$ resta a eterna indagação do antes do antes, à guisa do eterno retorno, um vício mental-conceitual da forma de pensar dialética, ou seja, da adoção do par conceitual princípio e fim. Os cientistas dirão: o big-bang é o estágio pelo qual, hoje, a ciência explica a origem do universo. Entretanto, saberes científicos que estarão por vir (futuros) poderão alterar essa origem do universo. Contudo, nessa forma de pensar da lógica binária, sempre haverá a pressuposição de uma origem, ou seja, de um princípio, uma exigência conceitual formal inerente ao pensar dialético, pois é impensável não existir origem, diferentemente do que pressupõe o pensamento rizomático, que se encontra sempre no meio da variação contínua da existência, sem princípio nem fim. Entretanto, constata-se que existe uma relação passional por parte da religião com a ciência, e também da ciência com a religião, questão bem caracterizada e iniciada no século XIX e ainda persistente em alguns setores de comunidades científicas e religiosas.

Nesse sentido, vale lembrar a criação da ciência cristã, um singular acontecimento que ainda sobrevive. Em decorrência do desenvolvimento científico do século XIX, nasceu, na cidade de

${ }^{2}$ Religião fundada pelo cientista L.Ron Hubbard em 1952 baseada em seus livros: A moderna ciência da saúde, Dialética: evolução da ciência da sobrevivência. A doutrina tem influências de outras religiões, hinduismo e budismo, e também, da psicologia.
Boston (1866), uma doutrina que se denominou ciência cristã, nome escolhido por Mary Bakr Eddy, que pregava a cura cristã, ou seja, a cura divina como o cumprimento natural feito por Jesus, um modo de vivenciar a salvação atual, completa e universal. É conhecida pelos cientistas cristãos como a Igreja-mãe. Vale salientar que essa é uma das manifestações que pretende expressar a cientificidade da religião. No Brasil, foi implantada, no início do século XX em São Paulo, por volta de 1912, e ainda sobrevive em poucas localidades do Planeta.

Retornando à nova forma de pensar, ao repertório conceitual do pensamento rizomático, nunca é demais repetir que o pensamento herdado da modernidade vem perdendo a hegemonia conceitual de que desfrutava. Conceitos tais como unidade, identidade, continuidade, evolução, ordem, organismo e sistema, entre outros, tão frequentes e hegemônicos nas formações discursivas do pensamento dialético herdado, vêm cedendo lugar, respectivamente, aos seguintes conceitos do novo pensamento: multiplicidade, diferença, descontinuidade (ruptura a-significante), evolução não linear (evolução a-paralela), caos (não no sentido de desordem, mas como lugar da criação, lugar de todas as formas, oceano da dessemelhança), corpo sem órgãos, rede (sistema aberto), entre outros.

Vale lembrar, por exemplo, que o conceito diferença esteve historicamente subordinado ao conceito identidade, pois sempre se pensou a diferença "na" identidade, o mesmo ocorrendo com o conceito multiplicidade, sempre subordinado ao conceito unidade. O pensamento moderno emancipou esses conceitos (multiplicidade e diferença), que se tornaram hegemônicos no pensamento contemporâneo.

Torna-se necessário esclarecer o conceito identidade (por exemplo, a identidade de uma religião, ou mesmo de uma área de conhecimento científico, filosófico ou artístico), pois se trata apenas de uma mera recognição, um reconhecimento de seus enunciados e práticas por suas manifestações de exterioridade (efeitos de superfície), embora se pressuponha a existência de algo, uma "essência", uma "coisa em si". Ledo engano, pois, em função da 
variação contínua da existência, em permanente transformação, e de nela estamos inseridos, não existem coisas em si, pois as coisas são relações e resultam da multiplicidade e heterogeneidade das conexões, pois, sempre nos encontramos no meio, no entre, no intermezzo de circunstâncias, situações, contextos históricos (econômicos, sociais, políticos e culturais). Portanto, não se torna necessário pensar em essências, coisas que permanecem, pois elas acompanham a variação contínua da existência, sem princípio nem fim. A identidade seria apenas uma afirmação na macroppolítica de características de setores sociais excluídos, ou de resistência de setores sociais hegemônicos às inevitáveis transformações da própria existência.

Tomemos, agora, por exemplo, o conceito totalidade, que pressupõe dois outros conceitos, todo e parte, em que as partes constituem mecanicamente, à guisa de um quebra-cabeça, o todo, formando, assim, uma unidade. Diferente, por exemplo, é o conceito totalidade fragmentária (ou segmentária) do pensamento rizomático, pois nele não se pressupõe o encaixe das partes no todo, mas a coexistência processual (dinâmica e não estática) de multiplicidade e heterogeneidade de elementos agenciados que estabelecem imprevisíveis conexões entre eles, pois não apenas se conectam, mas se sobrepõem, se entrelaçam, se cruzam, mantêm zonas de vizinhança, temporalidades (tempos) diferentes, promovem misturas, hibridações. Enquanto alguns elementos desaparecem, outros emergem, promovendo acontecimentos, criações, devires outros da existência, sem princípio nem fim.

O enunciado de Lavoisier "nada se cria, tudo se transforma" pode ter sua validade na materialidade do mundo da representação, no macro universo do real e do possível, ou seja, dos estratos físico-químicos, manifestações da matéria percebida, formada. Entretanto, nos estratos antropomórficos das relações humanas dos saberes-poderes, tudoé criado no micro universo da virtualidade, através de "matérias não formadas" (forças, fluxos, intensidades) que se manifestam nos desejos (não como carência, falta de algo, mas desejo de criar), e isso ocorre nos diagramas da composição de forças (potência, vontade de poder), na criação de novos conceitos na Filosofia, novas funções (functivos) na Ciência e novas percepções (perceptos) e afetos na arte. Tal fato pressupõe o conceito de "máquina abstrata" como matérias não formadas e funções não formais. Ela se opõe ao abstrato no seu sentido ordinário. Exemplificando, uma máquina abstrata, num "plano" tecnológico, expressa um diferente entendimento:

[...] não é composto simplesmente de substâncias formadas, alumínio, plástico, fio elétrico, etc., nem por formas organizadoras, programas, protótipos, etc., mas por um conjunto de matérias não formadas que só apresentam graus de intensidade (resistência, condutibilidade, aquecimento, estiramento, velocidade ou retardamento, indução, transdução...), e funções diagramáticas que só apresentam equações diferenciais, ou, mas, “tensores”' (Deleuze; Guattari, 2008, p. 227, grifos nossos).

Todavia a máquina abstrata se efetua e se compõe no plano de imanência, onde o pensamento adquire consistência e se orienta para pensar. Caso a forma de pensar seja a dialética, com sua lógica binária, a máquina abstrata será binária. Nesse sentido, o pensamento que incorpora desejos, vontades, afetos, fé, crença e esperança se configura como uma máquina abstrata pensante, constituída de matérias não formadas e funções não formais, embora mais complexa que as máquinas num plano tecnológico.

Voltando aos agenciamentos coletivos de enunciação e agenciamentos maquínicos, eles são saberes perpassados pela indissociável e invisível relação de poderes que acompanham as palavras e as coisas, no que se diz e no que se faz, seja nos ambientes confinados de família, igreja, escola, fábrica, caserna, hospital, entre outros dispositivos de controle das sociedades disciplinares que modelam os corpos, hoje em declínio, seja nos espaços abertos dos processos midiáticos das sociedades de controle. Tais sociedades modulam constantemente os corpos, pois o indivíduo, isoladamente ou em uma coletividade, é afetado com palavras de ordem, conceitos filosóficos (incorporais, virtuais, pois, não existem conceitos científicos; os conceitos são filosóficos e atualizados discursivamente nas funções 
científicas), e igualmente afetado por produções estéticas. No universo religioso, ele é afetado por dogmas, revelações e narrativas extraterrenas, pela pulsão de morte na espera de uma vida eterna, pois a alma se pressupõe ser imortal.

Esses saberes-poderes repercutem (se dobram) no dentro dos indivíduos, promovendo uma relação de si para si, uma relação de si para consigo mesmo e, ao mesmo tempo, como os outros e com mundo. Esse processo de interiorização constitui um construtivismo, uma fabricação que se denominou, como foi afirmado antes, de processo de subjetivação. Desse pressuposto conclui-se, a partir dos pressupostos anteriormente apresentados, que os indivíduos são construídos, considerando que eles se encontram no meio de uma multiplicidade e de uma heterogeneidade de conexões que expressam saberes e relações de poder. Tanto a ciência quanto a religião são específicos saberes-poderes transmitidos que afetam aqueles que os interiorizam e incidem na formação de suas construções subjetivas. Entretanto, a relação entre ciência e religião torna-se problemática, embora ocorrendo certa afinidade afetiva:

[...] o que é problemático é menos a relação da ciência com a filosofia do que a relação ainda mais passional da ciência com a religião, como se vê em todas as tentativas de uniformização e de universalização científicas, à procura de uma
Vale salientar que muitos cientistas, que tiveram, na construção de suas específicas subjetividades, a frequência de ambientes familiares e escolares religiosos, mantiveram a crença nos dogmas, revelações e narrativas transmitidos e, justamente por esse conjunto de saberes-poderes, eles foram basicamente afetados. Tal ocorrência explica a coexistência de práticas científicas com pressupostos de natureza religiosa, pois eles aliaram ao plano de transcendência religioso o plano de imanência científico, dois planos coexistentes nos quais o pensamento se orienta para pensar. Outros cientistas, embora tivessem tido semelhante orientação religiosa, aderiram apenas ao plano de imanência científico e, portanto, uns se tornaram agnósticos, indiferentes a essas questões, embora outros, mais combativos, tornaram-se descrentes e optaram pelo ateísmo como atitude ética, adotando uma específica visão de mundo. ${ }^{4}$

A esse respeito, vale evocar uma singular ocorrência. Em 1927, o físico Heisenberg apresentou o princípio da incerteza, também denominado princípio da indeterminação. Conta-se que alguns cientistas na época, inclusive Eisenstein, criador da teoria da relatividade, contestou esse princípio, pois, para ele, formado no âmbito da teologia hebraica, crente na ordem do universo sob a égide de um Deus único, teria dito: "Deus não joga dados".

Vale salientar que não existem apenas religiões monoteístas, mas também politeístas, embora entre elas haja um denominador comum, ou seja, a transcendência, a necessidade de acreditar em algo, em várias entidades que se encontram além da vida, em outros mundos, o que têm poderes de afetar a própria vida daqueles que nelas acreditam. Há crenças que diferenciam religiões através de específicas práticas (rituais). Algumas adotam a iniciação (batismo) ou rito de passagem, mas todas pressupõem a aprendizagem (transmissão dos saberes teológicos, catequese), cerimônias (rituais), orações, preceitos e normas (obrigações) que evidenciam as transgressões (desobediências, pecados que geram senti-

O Tratado de Ateologia de Michel Onfrey (2007) aborda a questão do ateísmo sob diferentes aspectos: monoteísmos, teocracia e a laicidade pós-cristã contemporânea. 
mento de culpa) e motivam práticas de purificação, confissão, exorcismo, penitências e oferendas. Todas as religiões têm seus lugares de culto (templos) que, em suas funções, expressam a escala hierárquica de seus ministros (padres, pastores, rabinos, aiatolás, pais ou mães de santo, entre outros).

Basicamente, como se afirmou anteriormente, sempre vale lembrar a diferença entre um crente e um ateu: o primeiro afirma que Deus criou o ser humano, enquanto que o ateu afirma que Deus é algo imaginado, ou seja, criação do ser humano. Entretanto é falso afirmar que um ateu não tem crença. Acreditar constitui uma das condições inalienáveis da existência, pois mesmo os mais radicais ateístas acreditam na imanência da própria vida aqui na terra, na possibilidade de abolir o controle divino e, mais ainda, de eliminar a invisível "coleira eletrônica" que as corporações das sociedades de controle impõem aos cidadãos, a exemplo de um incomensurável panóptico, orientando-os para o exacerbado consumismo sob a égide do marketing, ou seja, do capital informacional planetário que transforma tudo em mercadoria, inclusive a ciência e a religião.

Retomando o que se disse antes, a religião e a ciência, como diferentes saberes-poderes, são dobradas no "dentro" dos indivíduos, promovendo os processos de subjetivação, da relação de si para consigo mesmo, ou, coletivamente, entre os membros de uma formação social. O conceito dobra foi atualizado discursivamente por Deleuze em quatro instâncias: corpo, poder, sabere espera, evocando Foucault.

Em relação à dobra corpo, diferentes religiões condenam ou recomendam certas práticas, relacionadas com o corpo como organismo, particularmente em relação às atividades sexuais (continência), a restrições alimentares, à higienização do corpo (circuncisão, abluções diversas), à mortificação do corpo (jejum, penitência, flagelação), a coibir a nudez, cobrindo o corpo. Entretanto, é em relação às atividades sexuais que algumas religiões apoiam certas práticas (castidade, celibato, castração) ou condenam outras (pedofilia, homossexualismo, adultério aborto, violações genéticas, uso de células-tronco). Vale salientar que diferentes religiões realizam práticas que evocam um Deus único e, ao mesmo tempo, a presença de diferentes entidades do bem ou do mal (santos, beatos, espíritos, orixás, eguns, caboclos, demônios, espíritos malignos), como intercessores que visam a curar ou a manter a saúde do corpo e da alma, e até mesmo admitem a realização de milagres, ou então, promovem temerosos malefícios castigando as transgressões ou desobediências daqueles que neles acreditam.

A ciência, com seu plano de referência funcional em relação à vida, a dobra corpo, expressa um conjunto de conhecimentos que resulta de estudos, pesquisas e experiências, visando a combater doenças que se propagam e afetam a saúde dos seres humanos, eliminar o sofrimento (a dor) e prolongar a vida. Hoje, trata-se de uma área de conhecimento de elevada complexidade interdisciplinar que, além do corpo, se ocupa com a mente (psicologia, psiquiatria, neurologia, particularmente, as pesquisas relacionadas com a biogenética) e as complexas indeterminações na criação de novos organismos ou de duplica-los (clonagem).

Quanto à dobra do poder, torna-se evidente a presença de uma hierarquia, tanto na organização das práticas religiosas quanto científicas. O estabelecimento de uma delegação de autoridade exige dos crentes o reconhecimento e o respeito aos representantes divinos em seus diferentes níveis e graus da hierarquia funcional no desempenho das práticas religiosas. Essa aceitação hierárquica, como compromisso e submissão, é normalmente interiorizada e participa da construção subjetiva dos crentes. Todavia, nas comunidades religiosas, ocorrem rebeldias em relação a essa hierarquia estabelecida e aos ensinamentos transmitidos, fatos que permitem desterritorializações parciais e, portanto, a criação de derivações e (ou) seitas, até mesmo, a criação de novas religiões. Ou então ocorrem, com frequência bem menor, desterritorializações ou fugas para outros territórios existenciais, inclusive rebeldias exacerbadas que levam ao agnosticismo, ou, até mesmo, ao ateísmo.

Diferente, todavia também hierárquica, é a organização das práticas científicas, nas quais os poderes-saberes se concentram no reconhecimento e na aceitação de novas ideias, teorias, paradigmas 
ou da produção científica normalmente vinculada a universidades, laboratórios ou centros de pesquisa, muitos deles configurados em empresas. AUSP, como universidade pública, segundo critérios discutíveis, em publicação divulgada, ocupa a centésima vigésima sétima posição no ranking mundial de universidades em relação às universidades angloamericanas. Para não falar do poderio da NASA, que pesquisa e faz experiências no espaço sideral. Contudo, mesmo em relação às comunidades científicas constituídas, ocorrem dissensos e questionamentos que revelam formações subjetivas (individuais ou coletivas) de resistência aos saberes-poderes hegemônicos e constituídos.

Nesse sentido, é desejável a ocorrência de uma resistência criativa por parte dos cientistas, visando a inovações conceituais e tecnológicas, no âmbito de uma nova forma de pensar e, portanto, afirmar uma nova “visão de mundo" como atitude ética, ou seja, uma ação política (não partidária), a qual deveria resistir às formas de manipulação dos novos saberes e tecnologias a serviço do capital mundial integrado (CMI). Vale lembrar que não existe neutralidade dos saberes, pois eles, em suas manifestações hegemônicas, geram ações sobre ações (forças, poderes) que afetam multidões de indivíduos, considerando que os saberes produzidos são transformados em mercadorias, com valores de troca, e não valores de uso, visando a maiores lucros. Justamente por isso, emerge, nos processos de subjetivação, a dobra de contra-saberes-poderes, cujo objetivo é possibilitar que as conquistas científicas estejam ao alcance de qualquer cidadão que delas necessite.

Quanto à dobra do saber, embora indissociável do poder, ela se caracteriza pela exterioridade de suas manifestações, como agenciamentos coletivos de enunciação. Considerando que o saber e o poder são indissociáveis, pesquisas criativas e inovações tecnológicas, como bens imateriais, como se afirmou anteriormente, são promovidos ou capturados por empresas cujo objetivoéo controle ea comercialização de patentes, com a especulação que deles decorre. Nesse contexto, vale perceber que, no atual estágio da produção capitalista, a criatividade, como bem imaterial, passou a ser a matéria-prima fundamental do seu desenvolvimento, particularmente na economia. Justamente por isso, o apelo à economia criativa está tão presente em discursos recentes, inclusive, na área cultural. Vale lembrar a criação, em nosso país, de uma Secretaria de Economia Criativa no Ministério da Cultura. ${ }^{5}$

Resta abordar a dobra da espera, para a qual tanto a religião quanto a ciência têm diferentes objetivos que afetam profundamente a construção da subjetividade dos indivíduos ou de coletividades, embora haja uma espera comum em relação à vida, ou seja, a pulsão de morte. E, depois da morte, o que se espera? Via de regra, crentes de diferentes religiões, esperam a salvação, a vida eterna, ou mesmo uma reencarnação evolutiva no aprimoramento do espírito. Nas religiões monoteístas (hebraica, cristã e islâmica), por exemplo, no dualismo conceitual da imagem do pensamento, permanece a relação entre salvação e condenação, particularmente no cristianismo, entre o céu e o inferno, entre Deus e o Diabo e, para atenuar essa dramática contradição, cria-se, no cristianismo, um atenuante purgatório (estágio transitório de purificação) e um indefinido lugar, o limbo, para aqueles não batizados.

Na ciência, a dobra da espera relaciona-se com a vida e a saúde do corpo individual e de populações. Ela espera prolongar a existência e combater doenças e epidemias, Trata-se da área de conhecimento das ciências da vida, hoje um complexo campo de atividades multidisciplinares e interdisciplinares. Nesse sentido, os saberes-poderes das ciências da vida são dobrados pelos indivíduos que esperam a manutenção da saúde dos corpos. Nas ciências da terra, a espera é sempre a de inovações tecnológicas, particularmente hoje, com os dispositivos de informação e comunicação em tempo real, a maior velocidade dos meios de transporte e voos espaciais, entre outras conquistas, particularmente, a indústria bélica a maior do planeta. Todavia, não há muitos questionamentos que indaguem a quem servem essas conquistas científicas etecnológicas.

${ }^{5} \mathrm{Na}$ oportunidade em que o Ministério da Cultura adotou o tema "Economia Criativa", criando uma Secretaria específica, este autor publicou um artigo criticando sua conceituação (Magnavita, 2011, p.65). 
Mais indefinida e imprevisível ainda é a espera de resultados na área das ciências humanas e sociais aplicadas. Sem dúvida, trata-se de uma área de conhecimento bastante problemática, cujo dobramento nos indivíduos, via de regra, mais do que verdades e certezas, gera angústia, incertezas, indignação, frente à enorme desigualdade social existente, particularmente, entre aqueles que são excluídos, ou entre os que lutam para eliminar essa exclusão. Tal contexto social se caracteriza pela imprevisibilidade dos acontecimentos, pela insegurança generalizada e visível na violência urbana; pelo amplo desemprego; pela expansão do tráfico de drogas e de inúmeros problemas urbanos fundamentais (saúde, educação, moradia, acessibilidade, poluição do meio ambiente, entre outros).

Para a maioria da população, num país como o nosso, mais do que uma espera, torna-se um desespero, uma permanente angústia, e o papel ativo e criativo do saber científico visa à superação desse estado de coisas. Vale lembrar, todavia, que muitos desses saberes são apropriados para a manutenção do controle social existente, evidenciado pelo recente saber-poder da biopolítica. ${ }^{6}$ Diante dessa evidente realidade, as concepções monoteístas, em sua contemplação passiva, só podem atribuir esse estado de coisas à "vontade de Deus", que delegou o livre arbítrio. Nesse sentido, tem razão o pensador Giorgio Agamben, quando afirma que "Deus não morreu, Ele tornou-se dinheiro".

\section{CIÊNCIA, RELIGIÃO E APARELHO DE ESTADO}

Outra questão relevante e que merece atenção diz respeito à relação do aparelho de Estado, tanto com a ciência quanto com a religião, pois ele é um agenciamento concreto que efetua a máquina de sobrecodificação da sociedade. Entretanto, essa máquina não é o próprio Estado, como algo em si centralizado, mas trata-se de uma "máquina abs-

${ }^{6}$ Biopolítica, conceito atualizado discursivamente por Foucault como poder sobre a vida e que tem favorecido os poderes hegemônicos na manipulação de diferentes estatísticas. Entretanto, hoje, vem assumindo outro entendimento, não mais poder sobre a vida, mas, poder da vida! trata", com saberes-poderes de multiplicidade e heterogeneidade, dispositivos de controle (corporações, instituições, mídia, aparelhos de captura entre outros). Essa máquina organiza os enunciados dominantes e a ordem estabelecida de uma formação social, as línguas e os saberes dominantes, as ações e sentimentos codificados, os segmentos que prevalecem sobre os outros. Essa máquina abstrata de sobrecodificação assegura a homogeneização de diferentes segmentos (somos todos iguais perante a lei). Ela não depende do Estado, mas sua eficácia depende dele como agenciamento que a efetua em um campo social. Basicamente, o aparelho de Estado deve ser entendido como uma totalidade segmentária, a exemplo de uma rede aberta de multiplicidade e heterogeneidade de dispositivos, instituições e corporações que exercem micropoderes.

O aparelho de Estado, em sua relação com as ciências e as religiões (saberes científicos e saberes teológicos), tem se caracterizado historicamente, em seu exercício, pelo convívio e apoio à coexistência dessas duas formas de controle, ou seja, o da imanência política das verdades científicas codificadas e consensuais, mas também o da política da transcendência que emana de dogmas e revelações do além-mundo. E isso se dá como macropolítica, aproximando a ciência da religião. Nesse sentido, Max Weber, em seu tempo, não hesitou em aproximar o protestantismo do capitalismo industrial. Hoje, sem dúvida, pode-se afirmar que o protestantismo, em suas diferentes expressões e práticas (igrejas), se caracteriza pela afinidade que demonstra com alguns pressupostos do capitalismo pós-industrial, particularmente na adesão ao apelo consumista que ele promove.

\section{CIÊNCIA, RELIGIÃO E OS PROCESSOS DE SUBJETIVAÇÃO}

Por sua vez, a formação de um território existencial resulta, como se afirmou anteriormente, da dobra da relação entre saber e poder, o "fora" no "dentro" dos indivíduos, promovendo uma relação de si para consigo mesmo, para com os 
outros e o mundo. A relação entre saber e poder interiorizada afeta os indivíduos, mas não é determinante, pois a subjetividade, além de ser o lugar do consenso, é também, lugar do dissenso, ou seja, do saber-poder constituído e dominante ou do contra-saber-poder de resistência. Contudo, é também o lugar da criatividade. É justamente nesse universo molecular dos processos de subjetivação que se exerce a micropolítica. Não se trata de uma diferença de grau ou nível (dimensional) da macropolítica, pois ela é de diferente natureza. Vale salientar, todavia, que a criatividade como micropolítica da subjetivação, pode estar tanto a serviço do controle social hegemônico existente quanto voltada para a emancipação desse controle.

As verdades científicas, de um lado, e os dogmas e revelações, do outro, em uma perspectiva histórica, sempre foram coexistentes no universo tanto da macropolítica como no da micropolítica. Inúmeras são as ocorrências em que verdades científicas foram confrontadas e questionadas, permitindo a emergência de novas verdades e paradigmas. O mesmo ocorre com as religiões, dando origem a derivações ou criações de novas religiões, no âmbito de perseguições, tribunais de inquisição, fogueiras, guerras santas e genocídios, tudo sob a égide da "vontade de Deus", justificada pelo pressuposto e questionável livre arbítrio, dispositivo conceitual delegado aos seres humanos que gera o sentimento de responsabilidade etambém de culpa, introspecção subjetiva que pressupõe tanto a salvação quanto a condenação, ambas eternas.

\section{CIÊNCIA RELIGIÃOE ÉTICA}

A ciência enuncia verdades com suas funções que emanam da lógica do pensamento imanente. Por sua vez, a religião enuncia dogmas, revelações que emanam do pensamento transcendente, delegando ao além-mundo os poderes e o destino da vida, no reino de uma teocracia. Todavia, a laicidade militante no mundo ocidental apoiase, basicamente, na moral judaico-cristã, já que se constata uma reescrita imanente de um discurso transcendente, pois o que vem do céu não é abolido, mas adequado à vida na terra. Se analisarmos os manuais de moral nas escolas laicas republicanas, segundo Michel Onfray, eles permanecem no âmbito da moral judaico-cristã:

[...] ensinam a excelência da família, as virtudes do trabalho, a necessidade de respeitar os pais e venerar os velhos, a legitimidade do nacionalismo, as obrigações patrióticas, a desconfiança para com a carne, o corpo e as paixões, a beleza do trabalho manual, a submissão ao poder político, os deveres com os pobres. O que o cura da aldeia teria a replicar? 'Trabalho, Família, Pátria, santa tríade laica e cristã (Onfray, 2007, p.186).

Paradoxalmente, trata-se de um pensamento descristianizado, embora um pensamento cristão imanente, muito comum entre cientistas, filósofos e artistas, no qual coexistem, simultaneamente, a imanência e a transcendência.

Normalmente, confunde-se ética com moral, como se elas fossem a mesma coisa. A moral se caracteriza por um conjunto de princípios, prescrições, normas, atitudes e comportamentos codificados, que devem ser obedecidos socialmente. $\mathrm{O}$ não cumprimento desse conjunto de exigências se configura como transgressão, subversão, ato imoral que merece ser reprimido, castigado. Geralmente, como prática, a moral pressupõe tanto uma vida socialmente laica quanto religiosa, expressando uma ordenação necessária no âmbito de um poder hegemônico, seja ele civil, que emana da realidade social de uma determinada formação social, seja de uma teocracia de além-mundo.

A ética, por sua vez, preserva alguns modos de ser que emanam de uma moral já codificada. Entretanto, descodifica os pilares e vigas mestres da construção da moral hoje dominante, tanto laica quanto religiosa. Pois a ética, fundamentada na jurisprudência, que visa a uma prudente justiça social, parte de uma "visão de mundo" como atitude política e objetiva uma emancipação criativa do controle social existente, seja ele exercido pelas atuais "sociedades de controle" laicas do capitalismo informacional, que dominam os processos midiáticos da informação e comunicação, seja, 
então, do controle de diferentes religiões (particularmente as religiões monoteístas das sociedades ocidentais), as quais exercem poderes espirituais transcendentes e que, normalmente, são coniventes com o poder laico dominante, utilizando também os processos midiáticos das tecnologias avançadas para o exercício de suas práticas, que visam a zelar, persuadir e controlar comunidades religiosas e multidões de crentes.

Fala-se de ética capitalista, de ética protestante e de outras éticas de diferentes religiões. Todavia, trata-se de "éticas" voltadas para o controle de suas práticas e não, propriamente, para uma real emancipação desse controle. De um lado, o capitalismo, por exemplo, procura emancipar criativamente os indivíduos, induzindo-os para o exacerbado consumismo, tendo o marketing e o lucro como seu maior objetivo. Do outro, as religiões monoteístas prometem a emancipação imaginada da salvação da alma depois da morte, em uma vida eterna que estaria por vir. A ética a que nos referimos antes nada tem a ver com a ética imanente do capital ou de qualquer religião. Tratase do paradigma ético-filosófico-científico-estético como visão de mundo, no sentido de abolir os atuais controles, sejam eles de natureza imanente do modo de produção capitalista ou da produção espiritual ou transcendente de além-mundo.

\section{CONSIDERAÇÕES TRANSITÓRIAS}

Fazer considerações finais não foi o objetivo deste texto, mas apenas tecer um conjunto de pressupostos, conceitos, afirmações e questionamentos que resultam da forma de pensar deste autor (com base em um conjunto de pensadores contemporâneos) e que, sem dúvida, se configura de maneira diferente do pensamento de competentes colegas do Grupo de Ética da Academia de Ciências acerca do tema proposto: ciência e religião. De secular debate, esse tema é regido pela lógica binária, entre as matérias formadas que emanam da existência no universo macro (molar) do real e do possível do mundo da representação, coexistindo com o universo micro (molecular) do virtual e do atual, das matérias não formadas (fluxos, intensidades, desejos, fé, esperança), tanto no universo científico da imanência quanto na espiritualidade transcendente da imaginação do além-mundo. Basicamente, temse, de um lado, a ciência, com seu plano de referência funcional, a filosofia, com seu plano de imanência conceitual, e a arte, com seu plano de composição das percepções e afetos, e, do outro lado, o plano de transcendência do pensamento teológico voltado para o além-mundo.

Justamente, essa construção das subjetividades individuais e coletivas tem muito a ver com o que pensam cientistas e religiosos, pois depende de onde, quando e como eles construíram suas subjetividades, dobrando diferentes saberes-poderes e formando seus territórios existenciais autorreferentes, sejam eles territórios de natureza predominantemente científica ou religiosa, ou até mesmo, misturando-os. Nesse sentido, a subjetividade, além de ser lugar do consenso ou dissenso, é também o lugar da criatividade, ou seja, momento do ato de criação.

Contudo, dependendo do que se dobra do "fora" (saberes e poderes) no "dentro" de um indivíduo ou de uma coletividade, a criatividade pode estar relacionada com os saberes-poderes hegemônicos, promovendo sua aceitação, o consenso, ou então, com os saberes-poderes não hegemônicos, de resistência, de dissenso, ou seja, a emancipação criativa do controle social existente. Justamente por isso, tanto a ciência quanto a religião, como saberes-poderes específicos, devem pressupor os processos de subjetivação pelo relevante papel que eles desempenham na formação de uma micropolítica de subjetivação.

No atual mundo das sociedades de controle, do capitalismo mundial integrado (CMI), em que "Deus não morreu, Ele tornou-se dinheiro", tal fato ocorre tanto no universo científico quanto no religioso, pois ambos são afetados profundamente por essa condição vigente, na qual todas as coisas viram mercadoria, sejam elas materiais, imateriais ou simbólicas. No âmbito desse condicionamento favorecido pelas tecnologias avançadas e pelos 
processos midiáticos da informação e comunicação, tanto a ciência quanto a religião se inserem nesse condicionamento.

A ciência, com suas inovações patenteadas (bens imateriais materializados em produtos) em diferentes áreas de conhecimento, tem como objetivo obter o maior controle sobre os saberes produzidos e, ao mesmo tempo, o maior lucro em sua mercantilização. Entretanto, não é priorizada sua destinação para o atendimento de interesse social mais amplo (populações excluídas). Nesse sentido, basta lembrar apenas a comercialização da indústria farmacêutica e de outros serviços relacionados com a saúde, ao alcance apenas de minorias privilegiadas, e não, de forma mais abrangente, destinados à população como um todo.

Eisso para não falar das inovações tecnológicas bélicas. Vale lembrar que a indústria de armamentos é a primeira no ranking mundial, e nela se investe muito, pois a guerra não é apenas a conquista e controle de territórios, mas um surpreendente poder sobre a vida. Trata-se não apenas da bomba atômica e de suas temíveis consequências, mas de inovações tecnológicas como pequenos dispositivos teleguiados não tripuláveis, os "drones", que, digitalmente, matam a incomensuráveis distâncias, espionam áreas supostamente terroristas, controlam fronteiras, situações e contextos urbanos e rurais no Planeta Terra. Há, inclusive, outros dispositivos imperceptíveis que devassam a privacidade dos indivíduos - questão de maior atualidade em decorrência de denúncias veiculadas pela mídia, a exemplo de uma ficção científica de outrora e hoje uma realidade!

Igualmente, a religião se insere nesse contexto de dominação de bens imateriais, independentemente do dízimo que cobram dos fiéis. Outras atividades que geram renda e são veiculadas pela mídia (livros, CDs, filmes), bem como a realização de romarias a lugares sagrados espalhados pelo mundo afora, são estimuladas pela indústria turística (a segunda do ranking mundial depois da indústria bélica). Entretanto, destaca-se a propriedade de redes de informação e comunicação (mais laicas do que religiosas) que transmitem pra- ticas religiosas ao vivo e diariamente, intercaladas com chamamento publicitário repetitivo de produtos de todo tipo, como bebidas, veículos, produtos de beleza, apelo ao sexo, eletrodomésticos e até produtos farmacêuticos questionáveis, mensagens políticas, espetáculos midiáticos que objetivam persuadir os fiéis à aceitação do sistema de produção vigente, tornando os crentes inveterados consumidores. Ao mesmo tempo, repetem-se dogmas e revelações através de competente oratória e sedutoras programações audiovisuais, além de simulações que sugerem curas divinas, ou, até mesmo, práticas de exorcismo de entidades maléficas.

Este texto pode ser também entendido como um manifesto de um ateísta radical! Entretanto, a questão da fé não é privilégio dos que creem na transcendência, pois é uma condição humana da existência. Desde Espinoza, denominado por Deleuze o "Príncipe dos filósofos", a imanência e a ética se impuseram como "visão de mundo". Hoje, mais do que antes, acreditar numa emancipação criativa do controle social existente passou a ser um ato de fé, uma crença, ou até mesmo uma utopia. Que seja uma utopia, a exemplo de um horizonte por vir. Todavia essa modalidade de crença ou de fé promove uma incomensurável serenidade para o pensador, pois o ateísmo não é um dramático desvio da vida, da existência, mas uma positiva afirmação da imanência e, ao mesmo tempo, uma emancipação criativa da tirania da transcendência, ou seja, uma paradigmática conquista da Filosofia!

Recebido para publicação em 28 de julho de 2013 Aceito em 30 de agosto de 2013

\section{REFERÊNCIAS}

DELEUZE, G. Conversações. Rio de Janeiro: Editora 34, 2000.

. Diferença e repetição. Rio de Janeiro: Graal, 1988.

Lógica do sentido. São Paulo: Perspectiva, 1998.

Bergsonismo. São Paulo: Editora 34, 1999.

; GUATTARI, F. O que é a filosofia. Rio de Janeiro: Editora 34, 2000. 
: GUATTARI, Felix. Mil platôs, capitalismo e esquizofrenia. Rio de Janeiro: Editora 34, 1997/1999. 5v.

; PARNET, C. Diálogos. São Paulo: Escuta, 1998

FOUCAULT, M. As palavras e as coisas. São Paulo: Wmf Martins Fontes, 1981.

. Arqueologia do saber. Rio de Janeiro: Forense-Universitária, 1987.

- Vigiar e punir. Petrópolis: Vozes. 1999,

. História da sexualidade II. São Paulo: Graal, 2010.

. História da sexualidade III. São Paulo: Graal. 2011.

GUATTARI, F. Caosmose, um novo paradigma estético. Rio de Janeiro: Editora 34, 1993.
; ROLNIK, S. Micropolítica-Cartografia do desejo. Petrópolis: Vozes, 2005 esquizoanálise. São Paulo: Papirus, 1988.

HARDT, M.; NEGRI, A. Multidão, guerra e democracia na era do Império. São Paulo: Record. 2005.

MAGNAVITA, P. Economia criativa de resistência. Salvador: Edufba, 2011.

ONFRAY, M. Tratado de ateologia. São Paulo: Wmf Martins Fontes, 2007.

PELBART, P. Vida capital, ensaios de biopolítica. São Paulo: Iluminura. 2003. 


\section{SCIENCE AND RELIGION: toward a micropolitics of subjectivation}

\section{Pasqualino Magnavita}

This text is the result of the introduction of its author into a new philosophical Plane of Immanence, using new concepts via a new way of thinking, different from the binary, and still hegemonic, one. Any religion constitutes a form of knowledge (theology), and, as such, one deals with the historical stratification of knowledge, norms, and practices (that fold themselves in the interior of individuals, generating the construction of an individual or collective Existential Territory), which would be of a transcendent nature; that is to say, a belief in a world beyond ours. Contemporary thought considers the indissociability of the relation Knowledge/Power as well as the processes of subjectivation. This text is based in the conceptual triad of Immanence: Knowledge, Power, and Subjectivation. However, one discovers a certain affinity of Science with Technology (the "Science" of transcendental, spiritual powers), which coexist with and barely contest the "tyranny" of the State apparatus of the material powers of today's "Society of Control". Differently, atheism characterizes itself by its belief (faith) in Immanence and its evidencing of an Ethics ("vision of the world") as a political attitude aiming at emancipation from existent social control.

KEY-wORDS: Stratification. Existential Territory. Knowledge/Power. Fold. Subjectivation.

\section{SCIENCE ET RELIGION: pour une micro politique de subjectivation}

\section{Pasqualino Magnavita}

Ce texte est le fruit de l'insertion dans un nouveau Plan d'Immanence philosophique de l'auteur qui utilise de nouveaux concepts dans une nouvelle façon de penser dont la nature est différente de celle de la pensée binaire ou encore hégémonique. Toute religion est un Savoir (théologique), il s'agit donc d'une stratification historique de connaissances, de normes et de pratiques (qui se plient à l'intérieur des individus permettant la construction d'un Territoire Existentiel individuel ou collectif) mais qui est cependant de nature transcendante, c'est-à-dire la croyance en un monde au-delà du nôtre. La pensée contemporaine considère le caractère indissociable de la relation Savoir/Pouvoir, mais aussi des processus de subjectivation. Le texte se base sur la triade conceptuelle de l'Immanence : Savoir, Pouvoir et Subjectivation. Cependant il y a une certaine affinité entre la Science et la Théologie ("Science" de pouvoirs transcendants, spirituels), qui coexiste et ne conteste que peu la "tyrannie", de l'appareil d'État des pouvoirs matériels des "Sociétés de Contrôle" actuelles. Inversement, l'athéisme est caractérisé par sa croyance (foi) dans l'Immanence et met en évidence l'Ethique ("vision du monde") comme attitude politique visant à l'émancipation du contrôle social existant.

MotS-CLÉs: Strates. Territoire Existentiel. Savoir/ Pouvoir. Pliure. Subjectivation.

Pasqualino Romano Magnavita - Doutor em Arquitetura. Professor aposentado da Universidade Federal da Bahia. Integra o quadro docente do Programa de Pós-graduação em Arquitetura e Urbanismo da UFBA, ministrando disciplinas no Mestrado e Doutorado. Pesquisador do CNPq. Coordenador da Linha de Pesquisa Teoria e Crítica de Arquitetura e Urbanismo. Coordenador do Grupo de pesquisa "Lugar da Diferença micropolítica da subjetivação em Arquitetura e Urbanismo. Membro da Academia de Ciência da Bahia. Publicações recentes: Economia criativa de resistência: cultura e cidade-subjetividade e micropolíticaparadigma ético-estético. Cadernos PPG-AU/FAUFBA, v. especial, p. 65-79, 2011; A cidade exige, conclama, exorta: construa seu corpo sem orgãos. Debates em Estética Urbana. Salvador/BA: EDUFBA, 2010, p. 43-53. 